Journal of Social Sciences (COES\&RJ-JSS)

ISSN (E): 2305-9249 ISSN (P): 2305-9494

Publisher: Centre of Excellence for Scientific \& Research Journalism, COES\&RJ LLC

Online Publication Date: $1^{\text {st }}$ October 2016

Online Issue: Volume 5, Number 4, October 2016

http://centreofexcellence.net/J/JSS/JSS\%20Mainpage.htm

\title{
THE ENHANCEMENT OF HUMAN RESOURCES THROUGH THE \\ IMPLEMENTATION OF TOTAL QUALITY MANAGEMENT AT PR PRIMA IN MALANG, EAST JAVA-INDONESIA
}

Suyitno

Senior Lecturer of the STIE Indonesia Malang, East Java

\begin{abstract}
:
In increasing the quality of human resources, corporate can implement total quality management (TQM), by which an employee should do a job better, more effective and more efficient in producing the products with high quality and competitive price. The research aims to identify the implementation process of TQM, and its influence toward the quality of human resources. The result showed the variables of TQM (that is, employees role, employer role, relations of employer and employees, organizational aspects, and environ employees, organization aspects, and environmental aspects) are simultaneously have a significant influence toward the quality of human resources in PR. HF Prima Malang. The organizational aspects variable is dominantly influence the corporate's quality of human resources.
\end{abstract}

Keywords :

TQM implementation, human resources quality

\section{Citation:}

Suyitno (2016); The enhancement of human resources through the implementation of total quality management at PR Prima in Malang, East Java-Indonesia; Journal of Social Sciences (COES\&RJ-JSS), Vol.5, No.4, pp: 557-565. 


\section{BACKGROUND}

Human resources and employee management is very important to a company to manage and utilize its employee by which productivity can be enhanced to achieve the company goals. The professional human resources management can provide balances between the needs for workforces and the expectation and ability of the company. The company has been influenced by such balances and can grow naturally.

The globalization Era has efected the economic condition in the community business. Conseuantly, the business practitioners must face the the global challenges and manage to work or them careully. Failing to do this will cause the backdrop of the company. The business process has been moved on to the condition that the customers are coming to the producers and sellers, rather than the producers and sellers are coming to the customers. Such condition case the producers and sellers work for effective strategy to solve the company problem and manage the dynamic environment.

One of the important works to do is enhancing the quality of all working units and sectors one of which is human resources sector. In the micro environment, concerns on the human resources become the main problem in order to enhance the competitive advantage. One way to do this is implementing the Total Quality Management (TQM). TQM is an approach to operate business for maimiing organiazational competitive ability trough continuous improvement for its products, services, human resources, and working environment. To have the high competitive power, a company must be able to work or their business effectively and efficiently to produce high quality goods and services in clobal competition with competitive price (Sularso \& Murdijianto, 2004). The human resources management has turned out to be the most influential factor for such condition.

PR. HF Prima in Malang is one of the cigarete company in Malang region, East Java, Indonesia. This company produces the so called Kretek Cigarete by using competitive strategies to manage the competition among similar companies in Malang, East Java, Indonesia. The competition is a part of the company challenges. The other challenge has been the act that the local government suggests the community for not execively consuming the Kretek cigarete. One form of the suggestions is written in the cigarete package with the the ollowing sentence: "smoking can cause cancer, heart attack, impotance, and pregnancy as well as infant disorder". Effective numbers of products demanded by the community must be measured accurately and best services to provide the propper numbers and quality of cigarete needed by the community have to be managed. The company turned out to implement the Total Quality Management. . This research was aimed at finding out the process of Total Quality Management TQM) implementation and its influence to the quality of human resources at PR. Prima in Malang.

This research was limited to the TQM implementation in production section in which the TQM components included employee, leaders roles, relationship among leaders and employees, organiational aspects, and environemental aspects. 


\section{THEORETICAL REVIEWS}

Total Quality Management (TQM)

Total Quality Management (TQM) has been developed to be concelts of the final product quality, quality process, and quality of working environment (Heizer dan Render, 2005). Total Quality Management (TQM) is a set of concepts or principles of integrated sections or departments in a company to implement the continuous (Mulyadi, 1998; Tjiptono and Anastasia, 1995). Through such approach, it is expected that the company can maximize organiational competitiveness in terms of products, services, human resources, processes, and the environement (Edwards dan Collison, 1998; Glover dan Noon, 2005).

The characteristics of TQM (Tjiptono dan Anastasia, 1995) include focusing on both internal and external customers, quality concerns, scientific approach to take decision and problem solving, longterms commitment, team work, education and training, controlled freedom, united objectives, orderness, and employee empowerment (Jensen dan Wruck, 1997).

Nawawi (2003) states that the process of these characteristics implementation includes: (a) focusing on the customers with determined standards o measurement, (b) implementing active leadership accepting quality standard as well as actively and proactively determining quality standards. (c) quality concepts which is inline with the technology growth, (d) quality concepts development as the company culture, (e) focusing on the assumption that human resources quality influence all quality processes, quality production and products, uality services, and quality management functions, (f) approches to problem solving.

There are four main diferences between the TQM and other management approaches (Tjiptono dan Anastasia, 1995), which are (a) the theoretical basis o the TQM is statistics using sampling and varian analysis; (b) the innovation source of TQM was mostly produced by industrial techniue engineers and physical experts working in the industrial and governmental sectors; (c) The TQM concepts integrate the technical skills and analysis adopted from America, implementation and organiational skills adopted from Japan, and expertise and integrity tradition adopted from Europe and Asia; and (d) in the TQM process the workforces and driving forces are not just the CEO, but department managers or division managers.

\section{Human Resources Quality}

The TQM provide advantages to the company that can also increase the return on investement. The human resources quality development concerns the eforts to develop the technical ability, theoretical ability, conceptual ability, moral enhancement, and technical skills development through education and training (Martoyo, 2000). The aims of the human resources development is to improve the effectiveness and efficiency of works to achieve the company goals (Edwards dan Collinson, 1998). Education functions as the efforts to enhance the theoretical skills, conceptual skills as well as moral arttitude of human resources. Training functions at enhancing the technical skills, attitude, and responsibility of the employee in certain areas.

The improvement of the human resources capacity can be measured rom the success of the theoretical ability improvement in terms of the individual capacily in doing the industrial tasks, technical ability improvement in implementing working method and system, 
conceptual ability improvement in predicting success, the moral improvement in coordination, team work, colaboration, commiting to be truthful, doing individual proffesional development, and technical skills (Robbins, 2001).

The integrated management such as the TQM has been known to have efects to human resources (Marbun dan Heryanto, 1993). These include the effects of improvement in the roles of employees on becoming more diligent, more creative, more willing, more self development, and more trust; in the roles of leaders on becoming more active participative, more open in communication, closer to employees, and openess in communication, and more qualified in human relation (Glover dan Noon, 2005).

\section{Hypothesis}

Based on the theoretical review, the proposed hypothesis was the implementation of the total quality management (TQM) influenced the human resources quality.

\section{RESEARCH METHOD}

\section{Research Location}

This research was done at PR. HF. Prima in Malang, by the consideration of having this company implemented the Total Quality Management (TQM) in order to fulill the company standards. This condition attracted the researcher's interest to conduct the implementation of the Total Quality Management (TQM) which was conceptually considered to inluence the quality o human resources and help companies to improve their uality processes, services, and products. This research was an explanatory study which studied the causal relationship among variables through hypothesis testing (Singarimbun dan Effendi, 1995).

\section{Types and Sources o Data}

Types of data used in this research were qualitative and quantitative data. The qualitative data were sentences and description about the hystory o the company and production processes. The quantitative data was statistical data as results of questionnairs. There were primary and secondary data used in this research. The primary data were obtained from the first sources (Husein, 1999). The primary data were results of questionnairs obtained from the production section employees at PR. HF Prima in Malang.

The secondary data which were obtained rom the third party data collectors were used to support this research (Husein, 1999). The secondary data were the general profiles o the company and employees.

\section{Population and Samples}

Population was the overall subjects (Arikunto, 1998) in this reasearch. The population of this research was the production emplyees of PT. HF Prima in Malang. They were 216 people from four groups, which were, the grinding group, the cutting group, the warpping group, and the packaging group.

Sample, as a part of population is expected to obtain results showing the attitude and situation o the whole population (Sugiono, 1994). This research used proportional random sampling technique, taking random sampling and using propotional numbers of the population (Arikunto, 2998). The samples comprised 25\% of the 216 employees at 
the PR. HF Prima Malang Production Department, whiich were 54 respondents. Off the 54 respondents there were 5 people from the grinding and warpping units, 25 rom the cutting unit, bagian 8 people from the packing unit, and 17 people from the branding and bandrolling units.

\section{Definition of Operationalization and Variables of Measurement}

The independen variable of this research was the implementation of TQM (X), which was the business works done by the company to compete and uality for profitable and best products. These variables consist of the following indicators: Roles of employees (X1), Roles of Leaders (X2), Relationship between Employee and the Leaders (X3), Organiation Aspects (X4), Environmental Aspects (X5). The dependent variables were human resources qualities (Y), which were the abilities of the employees to work professionally. These Variabels consist of the following criterias: Theoretical ability (Y1), Technical ability (Y2), Conceptual ability (3), Moral ability (Y4), and technical skills enhancement (Y5).

Every query item was measured by Likert scale, where subjects must have been indicated on the basis of the levels towards the statements that relate to the objects' behavior (Sugiono, 2002). All values were combined to obtain total values showing the condition of the researched objects.

\section{Instruments Testing}

Prior to collecting the overall data, research instruments were tested. The questionnaires were tested to obtain the validy and reliability. Validity is a measurement based on the process of free from sistematic and random errors. Valid instuments mean that of being able to measure what to measure (Widayat, 2004). This research use Pearson validity usingn measurement criteria of Sig. $\leq \alpha(5 \%)$, and being valid if Sig. $>\alpha(5 \%)$. Reliability testing was meant that the instruments can be used to collect data due to having consistency of being good instrument (Widayat, 2004).

\section{Method of Data Analysis}

In data analysis, after collecting data the researcher clasify and anlize data using linier multiple regression approach measuring independent variable $(\mathrm{X})$ and dependant variable (Y) (Supranto, 1993). Then, the researcher conducted hypothesis testing using $F$-test and $\mathrm{t}$-test. Uji $\mathrm{F}$ (F-test) which aimed at measuring the simultanous influences or linier influences among independent variable which was the implementation of Total Quality Management (TQM) towards the dependent variable, which human resource qualities in PR. HF PRIMA Malang. To ensure the significance of the influences, the writer used Sig. $\leq \alpha$ which meant there were simultanous significances among independent variables towards dependent variables or Sig. $>\alpha$ which meant there were no simultabous influences among independent variabes towards the dependent variables. (Singarimbun dan Effendi, 1995).

\section{RESULTS OF THE RESEARCH}

\section{Description of research variables}

In table 1 it could be seen that role of employee (X1) gained average score of 3.71 approaching 4. This meant that most of respondents agreed that the role of employee was needed to implement TQM in PR. HF Prima Malang. The roles of leaders (X) gained average score of 3.73 approaching to 4 which meant that the roles of leaders were needed 
to implement TQM in PR. HF Prima Malang. The relationship of leaders and employees (X3) gained average score of 3.94 approaching 4 which meant that most responden agreed that such relationship was needed in implementing TQM in PR. HF Prima Malang. The organiational aspect (X4) gained average score of 4.10 approaching to 4 which meant that most of the respondents agreed that this variable was needed in implementing TQM in PR. HF Prima Malang.The environmental aspect (X5) gained average score of 4.07 approaching to 4 which meant most respondents agreed that this variable was needed to implement TQM in perusahaan PR. HF Prima Malang. Finally, human resource qualities (Y) gained score of 4.08 approaching to 4 which meant most respondents agreed that all employees of PR. HF Prima Malang must be adequately qualified.

\section{Table 1 Research variables description}

\begin{tabular}{clc}
\hline No. & \multicolumn{1}{c}{ Research Variables } & Average Scores \\
\hline 1. & Roles of Employees (X1) & 3,71 \\
2. & Roles of Leaders (X2) & 3,73 \\
3. & Relationships among leaders and employees (TX3) & 3,94 \\
4. & Organiational Aspects (X4) & 4,10 \\
5. & Environmental Aspects (X5) & 4,07 \\
6. & Human Resource Quality (Y) & 4,08 \\
\hline
\end{tabular}

Source : Primary Data was computes in 2012

\section{Instrument Testing}

The results of validity testing showed that the significant score (Sig) was smaller than $\alpha$ $(5 \%)$ which meant that the instruments were valid.

Table 2 Results of Multiple Regression

\begin{tabular}{|c|c|c|c|c|}
\hline Variabel & Beta & Standar Error & $\mathbf{t}$ & Sig. \\
\hline $\mathrm{X} 1$ & 0,258 & 0,064 & 4,025 & 0,000 \\
\hline $\mathrm{X} 2$ & 0,103 & 0,051 & 2,039 & 0,047 \\
\hline X3 & 0,172 & 0,064 & 2,703 & 0,009 \\
\hline $\mathrm{X} 4$ & 0,290 & 0,070 & 4,161 & 0,000 \\
\hline X5 & 0,155 & 0,062 & 2,497 & 0,016 \\
\hline Constanta & $: 5,061$ & & & \\
\hline $\mathrm{R}^{2}$ & : 0,891 & & & \\
\hline $\mathrm{R}$ & $: 0,944$ & & & \\
\hline $\mathrm{F}$ & : 78,741 & & & \\
\hline Sig. & $: 0,000$ & & & \\
\hline
\end{tabular}

Source : Primary data was computed in $2012(\alpha=5 \%)$

Reliability testing was the index showing that to what extend the instruments were trusted. In this research, the reliability testing was done by split half method and resulted the correlation score of 0,8593 , which was smaller than total correlation score of 0,9244 . This could be concluded that the instruments were reliable.

\section{Results of Data Analysis}

Result of the multiple linier regression showed that there was significant influence among dependent and independent variables with determination coeficient score $\left(\mathrm{R}^{2}\right)$ of 0,891 . This indicated that the implementation of Total Qaulity Management (TQM) comprising roles of the employees (X1), Roles o leaders (X2), relationship between leaders and 
employees (X3), organiational aspect (X4), environmental aspects (X5), and human resource quality (Y) in PR. HF Prima Malang was $89,1 \%$. The rest $10,9 \%$ was explained by other variables which were not included in this research.

The coeficience of the multiple correlation $(\mathrm{R})$ reached 0,944 showing that relationship among independent variables which included the roles of employees (X1), roles of leaders (X2), relationship among leaders and employees (X3), organiational aspects (X4), environmental aspects (X5), and human resource quality (Y) in PR. HF. Prima Malang were closely related due to having the $\mathrm{R}$ score approching 1 . Based on the multiple regression analysis, it can be formulated that the computation of multiple regression refered to independent and dependent variables relationship model as follows:

$$
\mathrm{Y}=5,061+0,258 \mathrm{X} 1+0,103 \mathrm{X} 2+0,172 \mathrm{X} 3+0,290 \mathrm{X} 4+0,155 \mathrm{X} 5
$$

From this formula it could be seen that each of the independent variables had positive influence towards the independent variable. This means that if one of the independent variables change, assuming all variables are constant, the dependent variables change, too.

\section{Result of Hypothesis Testing}

To find out whether the independent variable simultanously possesed signiicant relationship towards the dependent variables, the researcher used $\mathrm{F}(F-t e s t)$. Based on the table 2 it was found out that the F significant score was smaller than $\alpha(5 \%)$. The hypothesis was accepted showing that the implementation of the variables in the Total Quality Management (TQM) significantly influenced the uality of human resources. To ind out the individual influences of the independent variables towards the human resource qualities, t-test was used. Based on the table 2, the independent variables can be explained statistically that each o them had partial infulence towards the dependent variable due to having the $t$ significance score smaller than $\alpha(5 \%)$. From the result of the multiple linier regrression, it could be seen that the organiational aspect (X4) had domimant influence towards the qualities of the human resources.

\section{DISCUSSION}

From the personnels data, it was found out that the employees of the production unit were recruited from those as the house wifes or woman with consideration of needing accuracy and patience. Those woman were at the productive age which can support the productive results. Most of the employees graduated from primary schools, which showed that the production unit did not need higher educational background. They were considered to adeuately work in the production unit by having training. Most of the employees in production unit has been married showing that they were dependent responsibilities that motivated them to work harder. Most of them had workd in the company for 1 to 2 years. At the time o this research, they had a minimum salary of 1 million rupiahs per month. The recent secondary finding showed that such basic salary was more than the minimum regional salary of Rp. 550.000 per month.

Results of the employee aspects showed that the patience in developing employees were needed to reach the employee adecuate qualities. These included creativity, team work, and loyalty which develop the ability to conclude tasks. The ability to do self development was also needed, therefore opportunities to sel development and controlling were needed. The active roles of leaders were needed to create human resource qualituies and to ensure 
that all employees complied their responbsibilities. Leaders also needed to create conducive relationship and effective communication. The other environmental aspects were safe environement, conducive situation without any conflict, and the quality of leaders.

There were some concerns to be respon by the company, which were unity of mind, working climate, problem solving, mutual understanding, haemonic relationship, loyalty, voluntary action for better quality, adeuate facilities, clarity of roles and responsibilities, motivational programs, clarity of the company programs, theoretical capacity of the employees, technical and methodic capacity of the employees, conceptual ability of the employees, working morrales, professionalism, and risk-taking.

\section{CONCLUSION}

Total Quality Management (TQM) in controlling the human resource quality turned out to contribute to the company achievement. Some real steps could be done by the company in relation to the objectives. Firstly, the company respected the employees as the integrated parts of the working units to create harmonic relationship among the employees and management. Such condition could be showed by having employees who dedicated ownership of the company and the company to provide facilities to enable the employees work productively. Secondly, the company could give authority to enrole actively and creatively for the benefit of the company, opportunity to provide ideas and suggestion, and productive actions to support the company. Thirdly, leaders and the company always motivated employees to enable them work in accordance to the their roles and responsibilities. The company was epected to maintain harmonic relationship to create efective team work for the success of the company operational activities. Fourthly, leaders were expected to develop human resource uality by providing openness mind set and communication for decision making, career development, compensation and benefit, and performance management. Fifthly, the company was expected to improve the employees' welfare by refering to the employees levels of needs and the governmental regulation in order that the employees were motivated to work.

\section{REFERENCES}

Arikunto, S. 1998. Prosedur Penelitian Suatu Pendekntan Praktek. Jakarta:

Rineka Cipta.

Edwards, P. dan Collinson, M. 1998. The Determinants of Employee Responses to Total Quality Management: Six Case Studies. Organization Studies. Vol. 19, No. 3. Hlm. 449-475.

Glover, L. dan Noon, M. 2005. Shop-floor Workers' Responses to Quality Management Initiatives: Broadening the Disciplined Worker Thesis. Work Employment Society. Vol. 19, No. 4. Hlm. 727-745.

Heizer, J. dan Render, B. 2005. Operations Management. Jakarta: Penerbit Salemba Empat.

Husein, U. 1999. Riset Pemasaran Perilaku Konsumen. Jakarta: Gra-media Pustaka Utama.

Jensen, M. C. dan Wruck, K. H. 1997. Science, Specific Knowledge and Total Quality Management. Journal of Applied Corporate finance. Vol. 10, No. 2. Hlm. 247-287.

Marbun dan Heriyanto. 1993. Pengendalian Mutu Terpadu. Jakarta: Penerbit PT. Pustaka Binaman Pressindo. 
Martoyo. 2000. Manajemen Personalia. Bandung: Bintang Ilmu.

Mulyadi. 1998. Total Quality Management. Jilid Pertama. Yogyakarta: Penerbit Aditya Media.

Nawawi, H. 2003. Manajemen Stra-tegik, Cetakan Kedua. Yogya-karta: Penerbit

Gajah Mada University Press.

Singarimbun, M. dan Effendi, S. 1995. Metode Penelitian Survei. Jakarta: Penerbit LP3ES.

Sugiono. 1994. Metode Penelitian Bisnis. Bandung: Penerbit CV. Alfabeta.

Sularso dan Mardijianto. 2004. Manajemen Sumber Daya Mann-sia. Semarang: Genta Ilmu Persada.

Supranto, J. 1993. Ekonometrika. Jakarta: Penerbit LPFE-UI.

Tjiptono, F. dan Anastasia, D. 1995. Total Quality Management. Jakarta: Penerbit Andi Offset. 